\title{
PINDIT: an Online Digital Signage at Department of Electrical Engineering, University of Riau
}

\author{
Salhazan Nasution* \\ Informatics Engineering \\ Universitas Riau \\ Pekanbaru, Indonesia \\ salhazan@lecturer.unri.ac.id
}

\author{
Syachrodi \\ Informatics Engineering \\ Universitas Riau \\ Pekanbaru, Indonesia \\ syachrodi2016@student.unri.ac.id
}

*Corresponding author: Salhazan Nasution, salhazan@lecturer.unri.ac.id

\begin{abstract}
Digital information boards are widely used for displaying one-way information and announcements in a fast, precise, and up-to-date manner. In the Department of Electrical Engineering University of Riau, the media used to convey information and announcements is still conventional, which is using wall magazines and banners. This study aims to build a digital information board or Papan Informasi Digital (PINDIT), a web-based information system that will be displayed on a monitor screen or LED TV and placed in front of the Electrical Engineering office. The academic community or visitors can easily access information or announcements related to campus activities through these digital information boards. Information on PINDIT can be updated by administrators from anywhere via the internet and displayed in real-time. PINDIT uses Rasberry Pi as a device that connects the information system with the LED $T V$ screen, it also equipped with an RFID device which is used as a tool to record lecturers' attendance status in the room. We conducted Usability Testing for PINDIT on 33 respondents using the USE Questionnaire with aspects of learnability, efficiency, memorability, errors, and satisfaction. From the overall test results, PINDIT can be categorized as "Very Satisfactory" with an average percentage of each aspect of $86.23 \%$.
\end{abstract}

Keywords - Digital Signage, Information Board, Raspberry Pi, Web, RFID

\section{INTRODUCTION}

The Digital Information Board is one of the media used to convey one-way information quickly, accurately, and upto-date. The information conveyed takes advantage of technological advances and developments, where information will be displayed on the desired type of display, such as LCD Monitors, LED TV, Projectors, and Digital Billboards. The type of information displayed can be in the form of text, images, video, and audio.

In the Department of Electrical Engineering, the University of Riau, the media used in conveying information and announcements to academics and visitors still uses conventional methods. Information is conveyed by sticking an announcement paper on the magazine on the wall in front of the Department's room and using printed billboards every certain event. Of course, this method is less effective because of the limited amount of information that can be conveyed and it takes a long time to convey the information.

On this basis, the authors conducted further research on the delivery of information using digital technology in the form of an Online Digital Information Board at the Department of Electrical Engineering, University of Riau. The purpose of this research is to build a web-based information system that will be displayed on a monitor screen or LED TV and placed in front of the Electrical Engineering room at the University of Riau so that information related to academic activities can be conveyed quickly to students, lecturers, and visitors.

\section{BASIC THEORY}

\section{A. Digital Signage}

A digital information board or what is commonly called Digital Signage is a digital content management device or tool that is used to display information or announcements. Digital Signage can be installed indoors or outdoors with the intention that the information or announcements displayed can be received by the public quickly and up to date.

Digital information boards can contain information about important announcements, meeting schedules, video profiles, lecturer information, advertisements, events, and other important information. The information displayed has various multimedia formats, both in the form of images, videos, animated moving text, graphic data, and the like. All information will be displayed through electronic display media such as LCD TVs, Plasma TVs, digital billboards, projectors, or other devices. This digital information board can be controlled remotely via an internet network with a dynamic design display [1].

\section{B. CodeIgniter Framework}

CodeIgniter is a PHP framework developed by EllisLab.s which does not require any additional configuration. This 
framework does not use a specific command line. CodeIgniter is a lightweight framework, has a simple interface design and a logical structure. Besides, the documentation that is owned is also very complete because CodeIgniter has a large and friendly user community. CodeIgniter is Open Source and free to use as needed and supports the MVC concept that uses a Model-ViewController approach[2].

MVC is very useful to make it easier for programmers to do their job because by using MVC the program becomes more well structured. MVC is a programming technique that separates the application into 3 different components, namely model (data), view (design), and controller (process).[3].

\section{Raspberry Pi}

Raspberry $\mathrm{Pi}$ or also called RasPi is a microcomputer module the size of a credit card but has several digital input and output ports such as a microcontroller. Raspberry Pi was developed by the Raspberry PI Foundation with the original goal of being a computer science learning module in schools. Currently, the Raspberry Pi is equipped with wireless and Bluetooth connectivity on the latest models. The advantages of the Raspberry $\mathrm{Pi}$, when compared to similar microcontrollers, are that the Raspberry Pi is equipped with an HDMI port that can be connected to a display in the form of a monitor or the like. Not only that, but the Raspberry Pi is also equipped with a USB port that can be used for a mouse and keyboard[4].

\section{RFID}

Radio Frequency Identification (RFID) is one of the technologies used to build IoT-based systems. RFID consists of a tag or card, reader, and back-end program. There are two types of RFID tags, active tags which can transmit information without the help of a reader, and passive tags which require the reader to transmit information. RFID also has several frequencies ranging from low frequencies to microwave frequencies[5]. In the academic field, RFID is often used as a tool for recording attendance so that the attendance process can be done faster than conventional methods.[6].

\section{E. Usability Testing}

Usability testing (usability test) is a method that is carried out by asking the user of a product or system to perform a predetermined task to obtain data on usability problems, collect qualitative and quantitative data, knowing the user's working time in performing a given task, and how user perceptions about the system after testing.

Usability is an important attribute because it can explain and measure how easy it is for users to access and use the system. The word usability refers to a method that can increase the ease of use of a system during the design process[7].

The test method used in this study is the USE Questionnaire by conducting usability testing on 5 components, namely the ease of learning (learnability), efficiency (efficiency), easy to remember (memorability), error rate (errors), and level of satisfaction (satisfaction). [8]. Several previous studies have been conducted to test user satisfaction with an information system[9], at the University of Riau usability testing has been used to test user satisfaction with a system being built [10][11]

\section{F. Black Box Testing}

Generally, there are two techniques commonly used in testing, namely Black Box Testing and White Box Testing. Testing with the Black Box Testing method is the test most often used in research. The Black Box Testing method is carried out without knowing how the internal work is happening in the application system being tested or what is commonly known as the functional testing of a system[12].

Black box testing only focuses on testing the functionality of a system, such as testing the input and output of a system, whether the system being built is as expected or not. Usually, black box testing is done by the programmer who built the system[13].

Black box testing is used to test the features or menus contained in a system being built. This test only looks at the output of the data input process. That way it can be seen how the system's ability to meet the needs of its users and can find out what errors usually occur[14].

\section{G. Likert scale}

The Likert scale is a measurement scale that was first discovered and developed by Likert in 1932. The Likert scale is widely used in research in the form of surveys to measure opinions, attitudes, understanding of an individual or group about a particular thing or event which is a bipolar continuum scale. The Likert scale is widely used to determine the level of certainty in a study [15]. When responding to a statement, the respondent must choose one of the answers from several available answers as a form of agreement with the statement given. Usually given 5 types of scale options with the format as in Table 1.

TABLE I. LIKERT SCALE ASSESSMENT

\begin{tabular}{|c|c|}
\hline Answer Scale & Score \\
\hline Strongly Agree (SS) & 5 \\
\hline Agree (S) & 4 \\
\hline Neutral (N) & 3 \\
\hline Disagree (TS) & 2 \\
\hline Strongly Disagree (STS) & 1 \\
\hline
\end{tabular}

Meanwhile, to determine the percentage value of each score can be seen in Table 2.

TABLE II. PERCENTAGE OF LIKERT SCALE ASSESSMENT

\begin{tabular}{|c|c|}
\hline Percentage Value & Information \\
\hline $0 \%-20 \%$ & Very Unsatisfactory \\
\hline $21 \%-40 \%$ & Not satisfactory \\
\hline $40 \%-60 \%$ & Neutral \\
\hline $61 \%-80 \%$ & Satisfactory \\
\hline $81 \%-100 \%$ & Very satisfactory \\
\hline
\end{tabular}




\section{RESEARCH METHODOLOGY}

We made direct observations at the Department of Electrical Engineering, University of Riau the to see the actual conditions in the location, then we conducted study literature and data collection. From the results of observations and data collection, we carry out system analysis, design, and develop the system. In the end, we conducted direct testing and implementation at the research location to determine the impact of the research we conducted. The methodology used in this research can be seenthe Fig. 1.

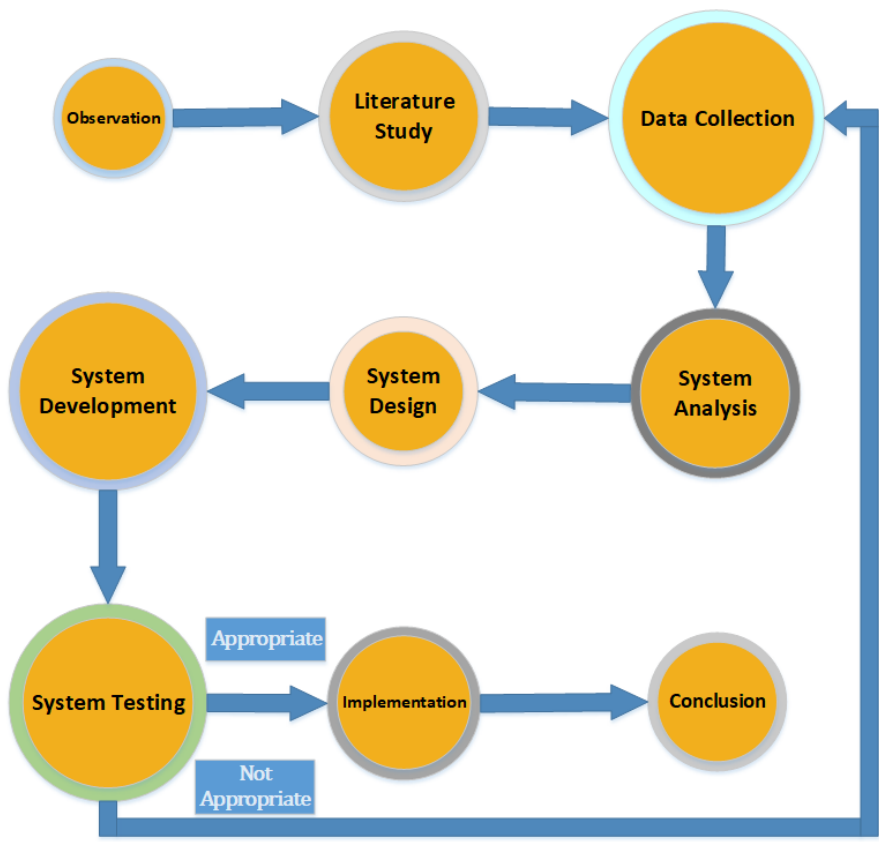

Fig. 1. Research methodology

\section{A. Observation}

Observation is a technique of collecting data by observing the object of research directly in the field without any intermediary. Observations were made to obtain data systematically. In this case, the observations were made at the Department of Electrical Engineering, University of Riau.

\section{B. Literature Study}

A literature study is a data collection method that is carried out by collecting data from several sources or references that are related to the research topic being carried out. The sources used can be in the form of books, journals, theses, theses, and other literature that have data and can be used as research support.

\section{Data collection}

We collect data by conducting observations and interviews with lecturers and administrative staff in the Department of the Electrical Engineering University of Riau, from these results we get information regarding what data is needed to build this system.

\section{System Analysis}

At this stage, we analyze the system requirements from the data we have previously collected. This stage determines how to design the database, design the interface, and design the program flow that will be used in building this system.

\section{E. System Design}

At this stage we design the interface using the Balsamiq Mockup, this stage is done as an initial step in interface design before it is made using the specified programming language. The results of interface design will be discussed with end-users who will use this system, if the design has been approved, it will proceed to the next stage.

\section{F. System Development}

At this stage, we build a system using the programming language PHP, HTML, Javascript and use MySQL as the database. The results of the design that has been done in the previous stages are implemented at this stage by building a web-based system.

\section{G. System Testing}

System testing is carried out to determine whether the system that has been madfollowing with the previous design and can be implemented properly. System testing is carried out to test whether there are errors in the system to be corrected before implementation. We tested this system using the Black Box Testing and Usability Testing methods.

\section{H. System Implementation}

The implementation stage is carried out if all stages of system development have been completed and the system is ready for use by users, namely the Department of Electrical Engineering, University of Riau.

\section{SYSTEM DESIGN}

System design is carried out to analyze and determine what is needed in the manufacture and use of digital information board systems.

\section{A. System Requirements}

There are several hardware and software we've used to build and implement this research. Hardware and software specification we've used to build the web-based Digital Information Board shown in Table 3.

TABLE III. HARDWARE AND SOFTWARE SPECIFICATION

\begin{tabular}{|l|c|}
\hline Processor & $\begin{array}{c}\text { Intel (R) Core (TM) i5-7200U } \\
\text { CPU @ 2.50 GHz 2.71GHz }\end{array}$ \\
\hline Memory (RAM) & 4.00GB DDR4 2133 MHz \\
\hline Hard Disk & $1 \mathrm{~TB}$ \\
\hline VGA & NVIDIA GeForce 930MX \\
\hline Operating system & Windows 10 Pro 64-bit \\
\hline Programming & HTML, PHP, JavaScript \\
\hline Database & MySQL Database \\
\hline Text Editor & Visual Studio Code \\
\hline System Design & Balsamiq Mockups 3 \\
\hline Browser & Google Chrome \\
\hline
\end{tabular}

Meanwhile, hardware specification we used to implement this Digital Information Board are Raspberry Pi type 3B, LED TV, USB RFID Reader, RFID Card, HDMI to VGA cable, MicroSD Card. 


\section{B. Data Flow Diagram (DFD)}

Data Flow Diagrams (DFD) describe the flow of data in a system, DFD functions themselves to explain the work processes of a system and help in understanding the system logically, well-structured and clear. The data flow diagram of this research can be seen in Fig. 2.

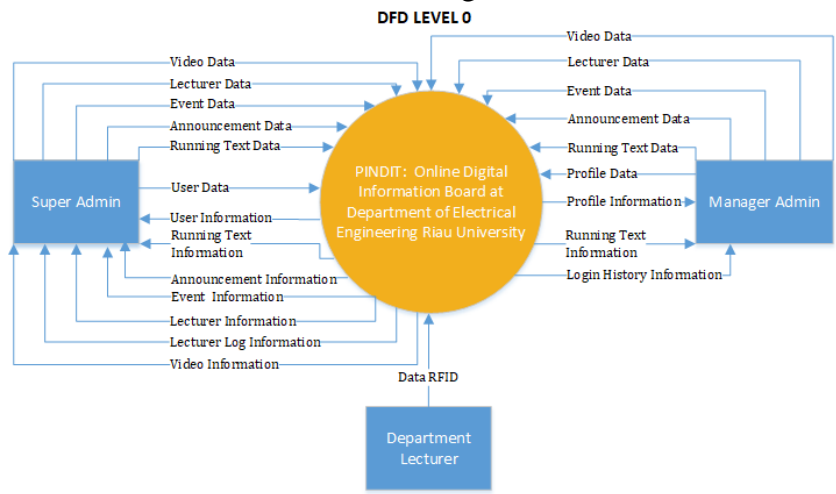

Fig. 2. Data Flow Diagram

\section{Flowchart}

Flowchart contains certain symbols that describe the sequence of processes contained in the system as a whole. The digital information board system flowchart is divided into several parts. The Super Admin dashboard flowchart can be seen in Fig. 3 .

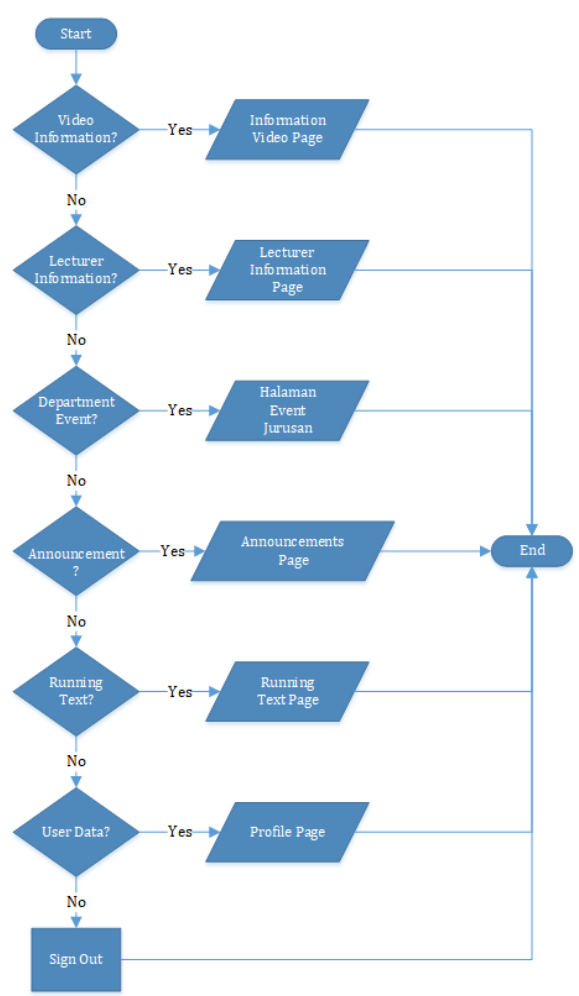

Fig. 3. Super Admin Dashboard Flowchart

The flowchart of the Lecturer Information Page can be seen in Fig. 4.

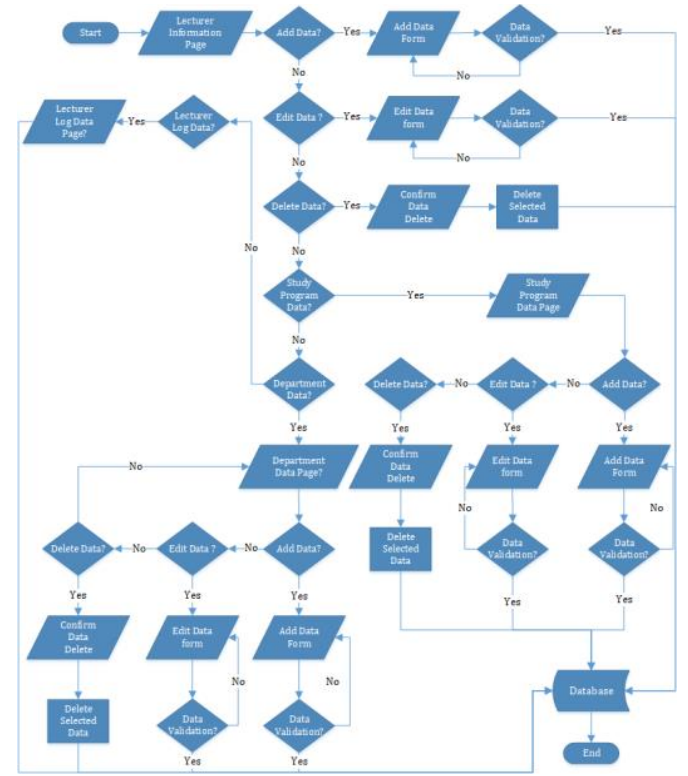

Fig. 4. Lecturer Information Page Flowchart

\section{RESULt}

\section{A. Digital Information Board}

The digital information board we've built displays several features such as lecturer attendance information, announcements, events, video, running text, and information about date and time. The digital information board will be displayed on the LED TV in front of the Electrical Engineering department at the University of Riau using the Raspberry $\mathrm{Pi}$ as a computer replacement. To access information and announcements from the Department, the academic community can easily view the digital information boards that have been provided. This system can also be accessed from anywhere with an internet connection. The information board display can be seen in Fig. 5 .

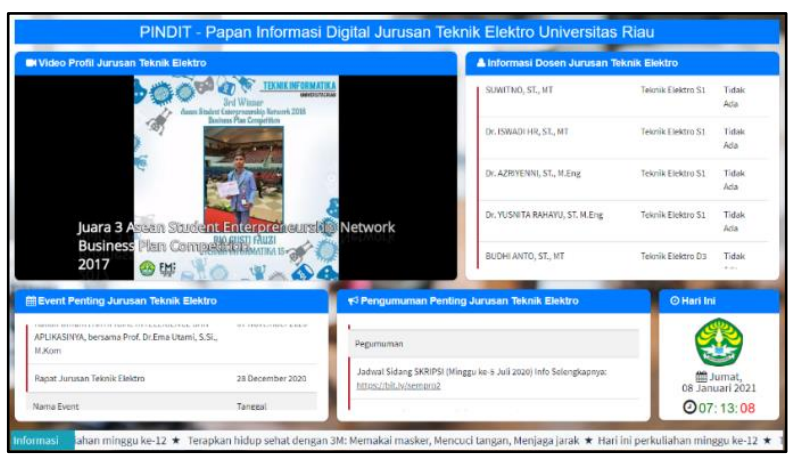

Fig. 5. Digital Information Board

To access the digital information board dashboard, the Administrator must log in first by entering their username, password and completing the google captcha on the login page. The login page display is shown in Fig. 6. 


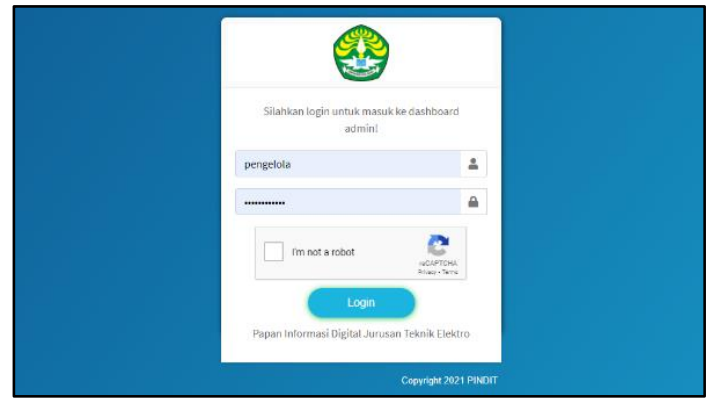

Fig. 6. Login page

If the user logged in successfully, it will be redirected to the dashboard page. On this page, there are several menus that Administrator can use to manage information on PINDIT such as video information management, lecturer information, event, announcement, running text menu, and user management. The Admin dashboard page display can be seen in Fig. 7.

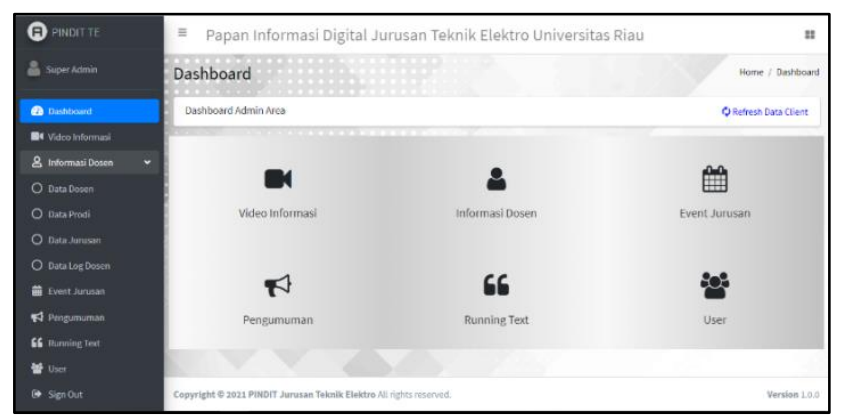

Fig. 7. Admin Dashboard page

One of the menus on the Admin's dashboard is video management. In this menu the Admin can update the videos that will be displayed on the screen, only one video can be displayed on the screen at a time. The videos that are displayed can be taken from YouTube, the Administrator only needs to insert the link of the video from YouTube to be displayed on PINDIT. Fig. 8 shown the video management menu.

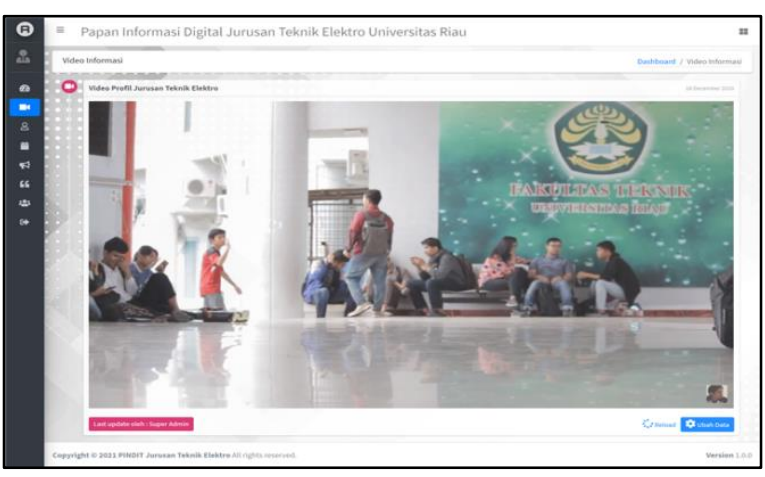

Fig. 8. Information Video page

In addition, there is also a lecturer information menu. The lecturer information menu contains lecturer name, lecturer id, attendance status, address, and others. Lecturer data will be displayed on a digital information board along with the Study Program where they are assigned and the status of their presence in the room. The display of the lecturer information page can be seen in Fig. 9 .

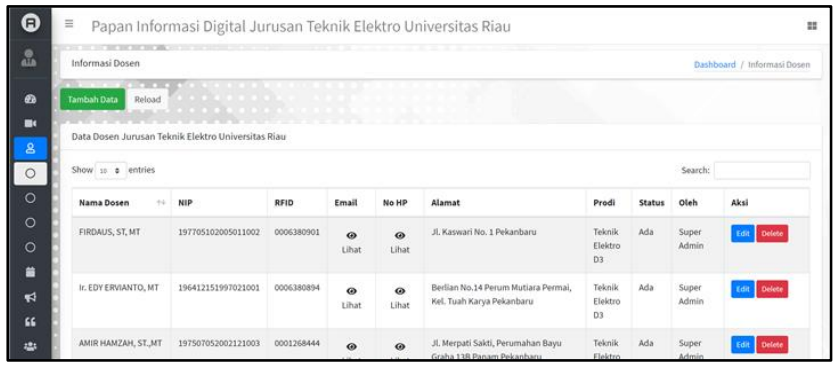

Fig. 9. Lecturer Information Page

On the digital information board menu, there is a feature that displays information about the lecturer's presence status in the room. By default the lecturer's presence status in the room is "Not Present", to change the status to be "Present", the lecturer must tapping the RFID Card data to the RFID reader which has been connected to the Raspberry Pi and connected to the Digital Information Board. Each lecturer has an RFID card with a unique code that is different from one another. If the tapping of the RFID Card data is successful, the lecturer status in the room will change to "Present". If the previous status was "Present", and the lecturer tapped the RFID Card, the attendance status will change to "Not Present". The display of digital information board system architecture can be seen in Fig. 10.

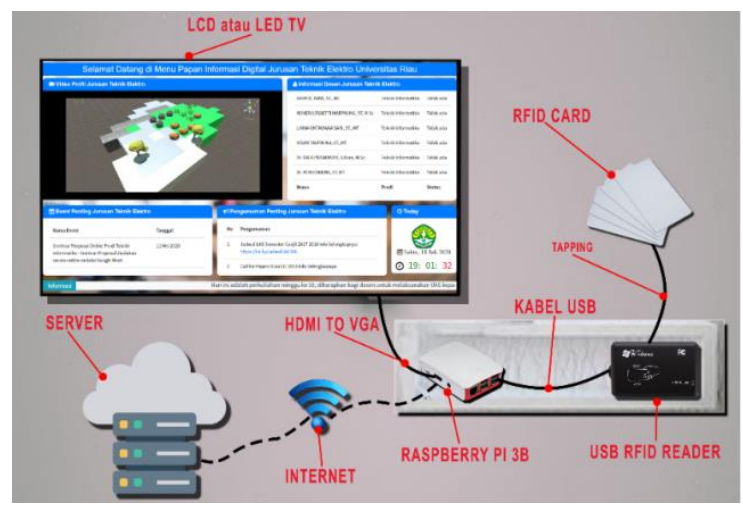

Fig. 10. Digital Information Board System Architecture

\section{B. Black Box Testing Results}

The results of the black box testing of the Digital Information Board system can be seen in Table 4.

TABLE IV. Black Box Testing Results

\begin{tabular}{|c|l|l|c|}
\hline \multirow{2}{*}{$\begin{array}{c}\text { No } \\
\cdot\end{array}$} & \multicolumn{2}{|c|}{ Black Box Testing Digital Information Board Systems } \\
\cline { 2 - 4 } 1 & $\begin{array}{l}\text { Testing Scenarios } \\
\text { username and } \\
\text { password blank }\end{array}$ & $\begin{array}{l}\text { Expected results } \\
\text { The system will deny } \\
\text { login access and } \\
\text { display a message to } \\
\text { fill in an empty form }\end{array}$ & Vanclusion \\
\hline 2 & $\begin{array}{l}\text { Adding Lecturer Data } \\
\text { (Incomplete data } \\
\text { entered), then click } \\
\text { submit }\end{array}$ & $\begin{array}{l}\text { The system will not } \\
\text { add data to the } \\
\text { database, but displays } \\
\text { a message "Data } \\
\text { cannot be empty" }\end{array}$ & Valid \\
\hline 3 & $\begin{array}{l}\text { Adding lecturer data } \\
\text { (inputted data is } \\
\text { complete) }\end{array}$ & $\begin{array}{l}\text { The system will save } \\
\text { the data into the } \\
\text { database and reload } \\
\text { the data table }\end{array}$ & Valid \\
\hline 4 & $\begin{array}{l}\text { Changing lecturer data } \\
\text { that has been stored }\end{array}$ & $\begin{array}{l}\text { The system will not } \\
\text { update the data in the }\end{array}$ & Valid \\
\hline
\end{tabular}




\begin{tabular}{|c|c|c|c|}
\hline \multirow[t]{2}{*}{ No } & \multicolumn{3}{|c|}{ Black Box Testing Digital Information Board Systems } \\
\hline & Testing Scenarios & Expected results & Conclusion \\
\hline & $\begin{array}{l}\text { (inputted data is } \\
\text { incomplete) }\end{array}$ & $\begin{array}{l}\text { database, but will } \\
\text { display a warning that } \\
\text { the data cannot be } \\
\text { empty }\end{array}$ & \\
\hline 5 & $\begin{array}{l}\text { Changing lecturer data } \\
\text { that has been stored } \\
\text { (inputted data is } \\
\text { complete) }\end{array}$ & $\begin{array}{l}\text { The system will } \\
\text { update the data stored } \\
\text { in the database and } \\
\text { reload the data table }\end{array}$ & Valid \\
\hline 6 & $\begin{array}{l}\text { Delete lecturer data } \\
\text { and select "cancel" } \\
\text { when confirming the } \\
\text { action }\end{array}$ & $\begin{array}{l}\text { The system will not } \\
\text { delete the lecturer data } \\
\text { that you want to delete }\end{array}$ & Valid \\
\hline 7 & $\begin{array}{l}\text { Delete lecturer data } \\
\text { and select "ok" when } \\
\text { confirming the action }\end{array}$ & $\begin{array}{l}\text { The system will delete } \\
\text { data that has been } \\
\text { confirmed for deletion }\end{array}$ & Valid \\
\hline 8 & $\begin{array}{l}\text { Adding announcement } \\
\text { data (input data is } \\
\text { complete and } \\
\text { according to the form) }\end{array}$ & $\begin{array}{l}\text { Add data for a } \\
\text { successful } \\
\text { announcement, data } \\
\text { will appear in the } \\
\text { announcement table, } \\
\text { alerts for success plus } \\
\text { data appear }\end{array}$ & Valid \\
\hline 9 & $\begin{array}{l}\text { Adding active running } \\
\text { text data (complete } \\
\text { data entered) }\end{array}$ & $\begin{array}{l}\text { Add data running text } \\
\text { with success, data will } \\
\text { appear in the active } \\
\text { running text table, } \\
\text { alert add data will } \\
\text { appear }\end{array}$ & Valid \\
\hline 10 & $\begin{array}{l}\text { Delete the active } \\
\text { running text data and } \\
\text { select "Ok" on the } \\
\text { confirmation of } \\
\text { erasing data }\end{array}$ & $\begin{array}{l}\text { Running text data is } \\
\text { deleted successfully, } \\
\text { deleted data will not } \\
\text { appear in active } \\
\text { running text table. }\end{array}$ & Valid \\
\hline
\end{tabular}

Based on the black box testing table, it can be concluded that the system is working as the user wants because the black box testing results are valid.

\section{Usability Testing Results}

Usability testing was conducted on 3 types of respondents which is Student, Lecturer, and Department Staff. The results of the student and lecturer Learnability component can be seen in Table 5 .

TABLE V. RESULTS OF THE LEARNABILITY COMPONENT (STUDENT AND LECTURER)

\begin{tabular}{|c|c|c|c|c|c|c|c|}
\hline \multirow{2}{*}{ Statement } & \multicolumn{5}{|c|}{ Assessment } & \multirow{2}{*}{$\begin{array}{l}\text { Total } \\
\text { Score }\end{array}$} & \multirow{2}{*}{$\%$} \\
\hline & STS & $T S$ & $N$ & $S$ & $S S$ & & \\
\hline $\begin{array}{l}\text { The PINDIT system } \\
\text { design interface is easy } \\
\text { to learn }\end{array}$ & & & & 10 & 19 & 135 & $93.1 \%$ \\
\hline $\begin{array}{l}\text { The content or } \\
\text { information displayed by } \\
\text { the PINDIT system is } \\
\text { specific (detailed) }\end{array}$ & & & 1 & 11 & 17 & 132 & $91.03 \%$ \\
\hline $\begin{array}{l}\text { The menu displayed is } \\
\text { easy to understand }\end{array}$ & & & & 8 & 21 & 137 & $94.48 \%$ \\
\hline \multicolumn{6}{|l|}{ Total } & 404 & $278.61 \%$ \\
\hline \multicolumn{6}{|l|}{ Average } & 134.6 & $92.87 \%$ \\
\hline
\end{tabular}

The results of the questionnaire for the student and lecturer Efficiency components can be seen in Table 6. The results of the student and lecturer Memorability component can be seen in Table 7. The results of the questionnaire on student and lecturer Errors component can be seen in Table 8.
TABLE VI. RESUlTS OF THE EFFICIENCY COMPONENT (STUDENT AND LECTURER

\begin{tabular}{|c|c|c|c|c|c|c|c|}
\hline \multirow{2}{*}{ Statement } & \multicolumn{5}{|c|}{ Assessment } & \multirow{2}{*}{$\begin{array}{l}\text { Total } \\
\text { Score }\end{array}$} & \multirow{2}{*}{$\%$} \\
\hline & STS & $T S$ & $N$ & $S$ & $S S$ & & \\
\hline $\begin{array}{l}\text { The information } \\
\text { provided is easy }\end{array}$ & & & 2 & 10 & 17 & 131 & $90.34 \%$ \\
\hline \multicolumn{6}{|l|}{ Total } & 131 & $90.34 \%$ \\
\hline \multicolumn{6}{|l|}{ Average } & 131 & $90.34 \%$ \\
\hline
\end{tabular}

TABLE VII. RESULTS OF THE MEMORABILITY COMPONENT (STUDENT AND LECTURER)

\begin{tabular}{|l|c|c|c|c|c|c|c|}
\hline \multirow{2}{*}{ Statement } & \multicolumn{5}{|c|}{ Assessment } & \multicolumn{1}{c|}{$\begin{array}{c}\text { Total } \\
\text { Score }\end{array}$} & \multirow{2}{*}{$\%$} \\
\cline { 2 - 7 } & STS & TS & N & $S$ & $S S$ & Score \\
\hline $\begin{array}{l}\text { The layout of the content } \\
\text { and information is easy } \\
\text { to remember }\end{array}$ & & & 1 & 16 & 12 & 127 & $87.58 \%$ \\
\hline Total & & & & & 127 & $87.58 \%$ \\
\hline Average
\end{tabular}

TABLE VIII. RESULTS OF THE ERRORS COMPONENT (STUDENT AND LECTURER)

\begin{tabular}{|c|c|c|c|c|c|c|c|}
\hline \multirow{2}{*}{ Statement } & \multicolumn{5}{|c|}{ Assessment } & \multirow{2}{*}{$\begin{array}{l}\text { Total } \\
\text { Score }\end{array}$} & \multirow{2}{*}{$\%$} \\
\hline & STS & $T S$ & $N$ & $S$ & $S S$ & & \\
\hline $\begin{array}{l}\text { The menu provided } \\
\text { worked well }\end{array}$ & & & & 15 & 14 & 130 & $89.65 \%$ \\
\hline \multicolumn{6}{|l|}{ Total } & 130 & $89.65 \%$ \\
\hline \multicolumn{6}{|l|}{ Average } & 130 & $89.65 \%$ \\
\hline
\end{tabular}

The results of the student and lecturer satisfaction component questionnaire can be seen in Table 9 .

TABLE IX. RESULTS OF THE SATISFACTION COMPONENTS (STUDENT AND LECTURER)

\begin{tabular}{|c|c|c|c|c|c|c|c|}
\hline \multirow{2}{*}{ Statement } & \multicolumn{5}{|c|}{ Assessment } & \multirow{2}{*}{$\begin{array}{l}\text { Total } \\
\text { Score }\end{array}$} & \multirow{2}{*}{$\%$} \\
\hline & STS & $T S$ & $N$ & $S$ & $S S$ & & \\
\hline $\begin{array}{l}\text { The design of the } \\
\text { PINDIT system is } \\
\text { comfortable and not } \\
\text { boring }\end{array}$ & & & 1 & 20 & 8 & 123 & $84.82 \%$ \\
\hline $\begin{array}{l}\text { The menu provided is in } \\
\text { accordance with the } \\
\text { system objectives }\end{array}$ & & & & 13 & 16 & 132 & $91.03 \%$ \\
\hline $\begin{array}{l}\text { Convenient when } \\
\text { accessing the PINDIT } \\
\text { system }\end{array}$ & & & 1 & 18 & 10 & 125 & $86.2 \%$ \\
\hline Total & & & & & & 380 & $262.05 \%$ \\
\hline Average & & & & & & 126.66 & $87.35 \%$ \\
\hline
\end{tabular}

The conclusion of the student and lecturer questionnaire results for each usability component can be seen in Table 10.

TABLE X. RESUlT OF THE STUDENT AND LECTURER USABILITY QUESTIONNAIRES

\begin{tabular}{|c|c|c|c|}
\hline $\begin{array}{c}\text { Responden } \\
\text { ts }\end{array}$ & Component & Percentage & Information \\
\hline \multirow{4}{*}{$\begin{array}{c}\text { Students } \\
\text { and } \\
\text { Lecturers }\end{array}$} & Learnability & $92.87 \%$ & $\begin{array}{c}\text { Very } \\
\text { satisfactory }\end{array}$ \\
\cline { 2 - 4 } & Efficiency & $90.34 \%$ & $\begin{array}{c}\text { Very } \\
\text { satisfactory }\end{array}$ \\
\cline { 2 - 4 } & Eemorability & $87.58 \%$ & $\begin{array}{c}\text { Very } \\
\text { satisfactory }\end{array}$ \\
\cline { 2 - 4 } & Satisfaction & $89.65 \%$ & $\begin{array}{c}\text { Very } \\
\text { satisfactory }\end{array}$ \\
\cline { 2 - 4 } & & $87.35 \%$ & $\begin{array}{c}\text { Very } \\
\text { satisfactory }\end{array}$ \\
\hline
\end{tabular}


From the table above, it can be concluded that all the usability components tested get a value above $80 \%$, with the lowest score being $87.35 \%$ for the satisfaction component and the highest score of $92.87 \%$ for the learnability component. Based on the final score obtained, it can be concluded that the tests carried out on the digital information board system got very satisfying scores from lecturers and students. The results of the Administrator learnability component questionnaire can be seen in Table 11.

TABLE XI. RESULTS OF THE LEARNABILITY COMPONENT (ADMINISTRATOR)

\begin{tabular}{|c|c|c|c|c|c|c|c|}
\hline \multirow{2}{*}{ Statement } & \multicolumn{5}{|c|}{ Assessment } & \multirow{2}{*}{$\begin{array}{l}\text { Total } \\
\text { Score }\end{array}$} & \multirow{2}{*}{$\%$} \\
\hline & STS & $T S$ & $N$ & $S$ & $S S$ & & \\
\hline $\begin{array}{l}\text { The PINDIT system } \\
\text { design interface is easy } \\
\text { to learn }\end{array}$ & & & & 4 & & 16 & $80 \%$ \\
\hline $\begin{array}{l}\text { PINDIT system } \\
\text { navigation flow is easy } \\
\text { to understand }\end{array}$ & & & & 4 & & 16 & $80 \%$ \\
\hline $\begin{array}{l}\text { The content or } \\
\text { information displayed by } \\
\text { the PINDIT system is } \\
\text { specific (detailed) }\end{array}$ & & & & 3 & 1 & 17 & $85 \%$ \\
\hline $\begin{array}{l}\text { The menu displayed is } \\
\text { easy to understand }\end{array}$ & & & & 3 & 1 & 17 & $85 \%$ \\
\hline $\begin{array}{l}\text { Does not require special } \\
\text { instructions to be able to } \\
\text { use the PINDIT system }\end{array}$ & & & & 4 & & 16 & $80 \%$ \\
\hline \multicolumn{6}{|l|}{ Total } & 82 & $410 \%$ \\
\hline \multicolumn{6}{|l|}{ Average } & 16.4 & $82 \%$ \\
\hline
\end{tabular}

The results of the questionnaire for the efficiency component of Administrator respondents can be seen in Table 12.

TABLE XII. RESULTS OF THE EFFICIENCY COMPONENT (ADMINISTRATOR)

\begin{tabular}{|c|c|c|c|c|c|c|c|}
\hline \multirow{2}{*}{ Statement } & \multicolumn{5}{|c|}{ Assessment } & \multirow{2}{*}{$\begin{array}{l}\text { Total } \\
\text { Score }\end{array}$} & \multirow{2}{*}{$\%$} \\
\hline & STS & $T S$ & $N$ & $S$ & $S S$ & & \\
\hline $\begin{array}{l}\text { The information } \\
\text { provided is easy to find }\end{array}$ & & & & 3 & 1 & 17 & $85 \%$ \\
\hline \multicolumn{6}{|l|}{ Total } & 17 & $85 \%$ \\
\hline \multicolumn{6}{|l|}{ Average } & 17 & $85 \%$ \\
\hline
\end{tabular}

The results of the Administrator memorability component questionnaire can be seen in Table 13 .

TABLE XIII. RESULTS OF THE MEMORABILITY COMPONENT (ADMINISTRATOR)

\begin{tabular}{|c|c|c|c|c|c|c|c|}
\hline \multirow{2}{*}{ Statement } & \multicolumn{5}{|c|}{ Assessment } & \multirow{2}{*}{$\begin{array}{l}\text { Total } \\
\text { Score }\end{array}$} & \multirow{2}{*}{$\%$} \\
\hline & STS & $T S$ & $N$ & $S$ & $S S$ & & \\
\hline $\begin{array}{l}\text { The navigation flow of } \\
\text { the system usage is easy } \\
\text { to remember }\end{array}$ & & & & 3 & 1 & 17 & $85 \%$ \\
\hline $\begin{array}{l}\text { The layout of the content } \\
\text { and information is easy } \\
\text { to remember }\end{array}$ & & & 1 & 2 & 1 & 16 & $80 \%$ \\
\hline Total & & & & & & 33 & $165 \%$ \\
\hline Average & & & & & & 16.5 & $82.5 \%$ \\
\hline
\end{tabular}

The results of the questionnaire for the Administrator Errors component can be seen in Table 14. The results of the questionnaire for the Administrator satisfaction component can be seen in Table 15. The conclusion of the Administrator questionnaire results for each usability component can be seen in Table 16.
TABLE XIV. RESULTS OF THE ERRORS COMPONENT (ADMINISTRATOR)

\begin{tabular}{|c|c|c|c|c|c|c|c|}
\hline \multirow{2}{*}{ Statement } & \multicolumn{5}{|c|}{ Assessment } & \multirow{2}{*}{$\begin{array}{l}\text { Total } \\
\text { Score }\end{array}$} & \multirow{2}{*}{$\%$} \\
\hline & STS & $T S$ & $N$ & $S$ & $S S$ & & \\
\hline $\begin{array}{l}\text { The menu provided } \\
\text { worked well }\end{array}$ & & & & 3 & 1 & 17 & $85 \%$ \\
\hline \multicolumn{6}{|l|}{ Total } & 17 & $85 \%$ \\
\hline \multicolumn{6}{|l|}{ Average } & 17 & $85 \%$ \\
\hline
\end{tabular}

TABLE XV. RESULTS OF THE SATISFACTION COMPONENT (ADMINISTRATOR)

\begin{tabular}{|c|c|c|c|c|c|c|c|}
\hline \multirow{2}{*}{ Statement } & \multicolumn{5}{|c|}{ Assessment } & \multirow{2}{*}{$\begin{array}{l}\text { Total } \\
\text { Score }\end{array}$} & \multirow{2}{*}{$\%$} \\
\hline & STS & $T S$ & $N$ & $S$ & $S S$ & & \\
\hline $\begin{array}{l}\text { The design of } \\
\text { PINDIT system } \\
\text { comfortable and not } \\
\text { boring }\end{array}$ & & & 1 & 3 & & 15 & $75 \%$ \\
\hline $\begin{array}{l}\text { The menu provided is in } \\
\text { accordance with the } \\
\text { system objectives }\end{array}$ & & & & 3 & 1 & 17 & $85 \%$ \\
\hline $\begin{array}{l}\text { Convenient when } \\
\text { accessing the PINDIT } \\
\text { system }\end{array}$ & & & & 4 & & 16 & $80 \%$ \\
\hline Total & & & & & & 48 & $240 \%$ \\
\hline Average & & & & & & 16 & $80 \%$ \\
\hline
\end{tabular}

TABLE XVI. RESULT OF THE ADMINISTRATOR USABILITY QUESTIONNAIRE

\begin{tabular}{|c|c|c|c|}
\hline $\begin{array}{c}\text { Responden } \\
\text { ts }\end{array}$ & Component & Percentage & Information \\
\hline \multirow{4}{*}{$\begin{array}{c}\text { Admin } \\
\text { Staff }\end{array}$} & Learnability & $82 \%$ & $\begin{array}{c}\text { Very } \\
\text { satisfactory }\end{array}$ \\
\cline { 2 - 4 } & Efficiency & $85 \%$ & $\begin{array}{c}\text { Very } \\
\text { satisfactory }\end{array}$ \\
\cline { 2 - 4 } & Memorability & $82.5 \%$ & $\begin{array}{c}\text { Very } \\
\text { satisfactory }\end{array}$ \\
\cline { 2 - 4 } & Errors & $85 \%$ & $\begin{array}{c}\text { Very } \\
\text { satisfactory }\end{array}$ \\
\cline { 2 - 4 } & Satisfaction & $80 \%$ & Satisfactory \\
\hline
\end{tabular}

From the Table above, it can be concluded that the overall usability component tested got a value above $70 \%$, with the lowest score being $80 \%$ for the satisfaction component and the highest score being $85 \%$ for the efficiency and errors component. Based on the final score obtained, it can be concluded that the tests carried out on the digital information board system get a very satisfactory score for the learnability, efficiency, memorability and errors components, while the satisfaction component gets a satisfactory score from the Administrator.

\section{CONCLUSION}

We have built PINDIT: a digital information board as a means of informing academic information in the Department of Electrical Engineering, University of Riau, and overcoming weaknesses in conventional methods that have been used so far. Information on PINDIT can be updated by Administrator from anywhere via the internet and displayed in real-time. PINDIT uses Raspberry $\mathrm{Pi}$ as a device that connects the information system to the LED TV screen and uses the RFID device as a lecturer attendance recording tool whose information is displayed in real-time on the screen. We conducted Usability Testing on 33 respondents using the USE Questionnaire with aspects of learnability, efficiency, memorability, errors, and satisfaction. From the overall test 
results PINDIT can be categorized as "Very Satisfactory" with an average percentage of each aspect of $86.23 \%$.

\section{REFERENCES}

[1] Y. Park, H. Yang, T. Dinh, and Y. Kim, "Design and implementation of a container-based virtual client architecture for interactive digital signage systems," Int. J. Distrib. Sens. Networks, vol. 13, no. 7, p. $1550147717717864,2017$.

[2] S. R. Mandaviya, R. K. Raval, and A. B. Parekh, "The MVC Framework-Codeigniter," Int. J. Nov. Res. Dev., vol. 2, no. 5, pp. 23-27, 2017.

[3] F. M. Kromann, Beginning PHP and MySQL: From Novice to Professional, 5th ed. Apress, 2018.

[4] R. Panuntun, A. F. Rochim, and K. T. Martono, "Perancangan Papan Informasi Digital Berbasis Web pada Raspberry pi," J. Teknol. dan Sist. Komput., vol. 3, no. 2, pp. 192-197, 2015.

[5] P. Tan, H. Wu, P. Li, and H. Xu, "Teaching Management System with Applications of RFID and IoT Technology,” Educ. Sci., vol. 8, no. 1 , p. 26 , Feb. 2018.

[6] S. Nasution, "Presensi Online Menggunakan RFID pada Kartu Mahasiswa," INTECOMS J. Inf. Technol. Comput. Sci., vol. 1, no. 1, pp. 19-27, Mar. 2018.

[7] D. R. Rahadi, "Pengukuran Usability Sistem Menggunakan Use Questionnaire Pada Aplikasi Android,” J. Ilm. Jur. Sist. Inf., vol. 6, no. 1, pp. 661-671, 2014.
[8] A. Madan and S. Kumar, "Usability evaluation methods: a literature review,” Int. J. Eng. Sci. Technol., vol. 4, 2012.

[9] S. Nasution and A. Mulyadi, "Revenue and Tourist Reporting Application for the City of Pekanbaru," Int. J. Electr. Energy Power Syst. Eng., vol. 3, no. 1, pp. 17-23, 2020.

[10] S. Nasution and R. A. Frianti, "Sistem Informasi Inventori Obat Berbasis Web di Rumah Sakit Universitas Riau," Semin. Nas. APTIKOM 2019, vol. 0, no. 0, pp. 402-409, Nov. 2019.

[11] S. Nasution and M. B. P. Sari, "Sistem Informasi Kepegawaian Rumah Sakit Universitas Riau Berdasarkan Standar Nasional Akreditasi Rumah Sakit (SNARS),” IT J. Res. Dev., vol. 5, no. 1, pp. 1-10, 2020.

[12] D. R. K. Dwivedi, M. Kumar, and S. K. Singh, "A Comparative Study of Black Box Testing and White Box Testing Techniques," Int. J. Adv. Res. Comput. Sci. Manag. Stud., vol. 3, no. 10, pp. 3244, 2015.

[13] N. Muhajirin and W. Daryono, "The use of Digital Signage as Media Campus Information (Penggunaan Digital Signage sebagai Media Informasi Kampus)," J. Pekommas, vol. 3, no. 1, p. 1, Sep. 2018.

[14] K. T. M. Rizal Panuntun, Adian Fatchur Rochim, "Perancangan Papan Informasi Digital Berbasis Web pada Raspberry pi," J. Teknol. dan Sist. Komput., vol. 3, no. 2, pp. 191-197, 2015.

[15] S. Syofian, T. Setiyaningsih, and N. Syamsiah, "Otomatisasi Metode Penelitian Skala Likert Berbasis Web," Pros. Semin. Nas. Sains dan Teknol. 2015, vol. 1, no. 1, pp. 1-8, 2015. 